\title{
Identity and action: Help-seeking requests in calls to a victim support service
}

\section{Emma Tennent}

\section{Victoria University of Wellington, New Zealand}

The nature of the link between identity and action is a fundamental question for social science. One focus in psychology is how actions like seeking help are implicated in matters of identity. This paper presents a discursive psychology study of identity and help in social interaction. Drawing on a corpus of nearly 400 recorded calls to a victim support helpline, I analysed how participants oriented to the link between identity and help. With attention to epistemic, deontic, and affective relations between participants, I analysed how identity was demonstrably relevant and procedurally consequential for building and interpreting help-seeking requests. Participants displayed an understanding that seeking help from Victim Support necessarily implicates identity. Callers' identities as victims or clients rendered their help-seeking accountable and invoked identities for call-takers as representatives of a support service. The findings show that identity and help are mutually constitutive. Seeking help constituted callers' identities as victims; and their identities as victims constituted their requests for help. I suggest that analysing identity and help in social interaction provides evidence for the mutually constitutive link between identity and action.

Identity shapes how people see themselves, relate to others, and engage with the social world (Benwell \& Stokoe, 2006) and has been theorised as the link between individual actions and social structure (Hogg et al., 1995; Jaspal et al., 2016). In this paper, I analyse the link between identity and action by examining how identity matters for help-seeking. With analysis of naturally-occurring calls to a victim support helpline, I examine how participants build links between identity and action through the turn-by-turn unfolding of social interaction.

One way the relationship between identity and help-seeking has been examined is by documenting how identity influences rates of help-seeking behaviours. Social identity theory (Tajfel \& Turner, 1986) posits that seeking help can threaten aspects of individuals' personal or social identities. For example, seniors may not seek help after a fall to preserve their sense of independence (Miller et al., 2016) and people experiencing depressive symptoms may delay seeking help to preserve their sense of identity and personal goals (Farmer et al., 2012). Adopting a new identity may be necessary before help-seeking can occur. For example, women may conceal experiences of domestic violence to preserve a public identity, but when this becomes untenable, they can adopt an 'abuse identity' from which help-seeking is possible (O'Doherty et al., 2016). However, the act of seeking help can require a balance between social and personal identities to articulate individual needs against group identification (Read et al., 2015). Thus, identity can influence individual help-seeking decisions and behaviour. 
An alternative approach examines how people display who they are to each other when seeking help. Rather than conceptualising help-seeking as behaviour influenced by identity, discursive psychology demonstrates how different constructions of identity are used to accomplish help in social interaction. People use identity categories to make sense of the social world (Edwards, 1998) and systematically accomplish actions (Stokoe \& Edwards, 2009). Seeking help is a social action with a normative and sequential organisation (Edwards \& Stokoe, 2007; Kendrick \& Drew, 2016) that implicates identity and self-other relations. In this paper, I analyse participants' orientations to identity and help, and examine how identity renders help-seeking intelligible and accountable.

The relationship between identity and help stretches back to the earliest work in conversation analysis. Sacks' (1967) seminal analysis of a suicide helpline documented how identity categories and social relations provide a normative organisation for help-seeking. Relational categories are "a locus of rights and obligations concerning the activity of giving help" (Sacks, 1967, p. 203). Members of certain relationship categories (e.g. friends or family) are normatively proper to turn to, while members of other categories (e.g. strangers) are improper to seek help from. A fundamental assumption of many service-providers is that certain kinds of problems (such as suicide or victimisation) require professional help. Yet even though service-providers may see themselves as professionals with proper knowledge and expertise to help, callers may categorise them as strangers whom it is improper to turn to (Sacks, 1972a). Thus, membership categories, as stores of common-sense knowledge, provide shared cultural resources to determine who can be turned to for help.

Common-sense cultural meanings associated with membership categories are a resource for participants to account for seeking help. In online forums, for example, participants use identity claims to account for seeking help and provide support to others (Giles, 2006; Lamerichs \& te Molder, 2003; Smithson et al., 2011). Horne and Wiggins (2009) documented how posts to an online suicide support forum managed the tension between asking for help and presenting an authentic suicidal identity. Posts regularly avoided asking for help directly, and instead worked up a suicidal identity by demonstrating being psychologically 'on the edge.' Negotiating moments of crisis by ignoring or acknowledging others' responses allowed forum members to seek support while maintaining their own and others' identities as authentically suicidal (Wiggins et al., 2016). Participants orient to their own and others' identities as key resources in determining the accountability of seeking help.

In institutional contexts such as helplines, callers must balance the normative accountability of asking for help alongside the accountability of turning to an institution (Edwards \& Stokoe, 2007). Presenting a relevant institutional problem can invoke callers' identities or social positions relative to the problem (Whalen \& Zimmerman, 1990). However, establishing a joint understanding of callers' relevant identities and what help they need is a negotiated accomplishment. For example, MensLine is an Australian relationship helpline that identifies clients as men and offers solution-focused counselling based on the presumption men want instrumental help rather than emotional support. Yet many callers claim they simply want to talk (Feo \& LeCouteur, 2013). Similarly, the Kids Help Line identifies clients as children and offers child-centred counselling based on the presumption children can make their own decisions. Counsellors make these philosophies manifest when they let callers decide how to present their problems and avoid giving direct advice (Butler et al., 2010; Danby et al., 2005). But not all callers are seeking to be empowered, and some ask 
for help directly (Emmison \& Danby, 2007). Thus, establishing help-seekers' relevant identities is bound up with how help is sought and offered.

Seeking help configures identities and social relations in accountable ways. Participants orient to normatively accountable ways, times, and people to properly ask for help. The link between identity and help is also accountable in Garfinkel's (1967) sense of intelligibility. Participants' identities are resources for building and interpreting actions. For example, requesting help is an action that inevitably displays a speaker's understanding of their entitlement to help, their identity vis à vis their recipient, and the basis of the relationship between them (Levinson, 2013). Thus, identity is a resource to build actions that are recognisable as help-seeking.

Stevanovic and Peräkylä (2014) theorised that identities and social relations - participants' shared sense of who-they-are-to-each other - are grounded in epistemic, deontic, and affective orders. Participants' orientations to their respective rights to knowledge, power, and emotion are fundamental resources for building and interpreting actions. The epistemic order refers to the connections between people based on knowledge. Participants negotiate who they are and what they are doing by managing their rights to own and express knowledge (Heritage, 2012; Mondada, 2013; Raymond \& Heritage, 2006). The deontic order refers to the social organisation of power or authority in terms of participants' relative "rights and obligations in requesting for, deciding about, and performing actions in the world" (Stevanovic \& Peräkylä, 2014, p. 190). The affective order refers to participants' rights to own certain emotions and express them to others. These three orders are resources for participants to understand who they are to each other and what they are doing.

The way social relations are rendered visible in social interaction has been usefully conceptualised by Heritage (2012) in terms of status and stance. Epistemic status refers to participants' joint recognition of what they know relative to others, how they know it, and their rights and responsibilities to articulate this knowledge. Epistemic stance refers to participants' moment-by-moment expression of these relative rights to knowledge through the design of turns of talk. Similarly, participants' distributed rights to enact actions and to own and express emotions can be conceptualised as deontic and affective status, and their momentary unfolding in talk as deontic and affective stance (Stevanovic \& Peräkylä, 2014). Analysing participants' orientations to shifting distributions of knowledge, power, and emotion thus provides a grounded way to examine the link between identity, social relations, and action as they come to matter in social interaction.

In this paper, I analyse how participants orient to and invoke the relationship between identity and help in calls to a victim support service. The name of the service - Victim Support links a victim identity with accessing support. The context thus provides a perspicuous setting for such analysis (Garfinkel, 2002) because the relationship between identity and helpseeking is demonstrably relevant for the participants and procedurally consequential for the interaction (see Schegloff, 1997). In the course of routine workday tasks, helpline call-takers are involved the political, moral, and psychological enterprise of determining who callers are and who is obligated to help them. Such tensions have been documented in other institutional gate-keeping contexts (Heritage \& Clayman, 2010), but are particularly fraught when a victim identity is relevant (see Löfstrand, 2009; Simmonds, 2009). 


\section{Data and Method}

\section{Background}

Victim Support New Zealand is a community organisation that provides free services to victims of crime and trauma. A regionalised network of support workers provides emotional support and practical advice in clients' homes, over the phone, or at local police stations. A national Contact Service manages multiple phone lines, including the victim helpline for the public which is the context for this study. The helpline is designed as a conduit to service for clients to access support workers and a first point of contact for victims who are entered into the database and allocated a support worker.

\section{Data corpus}

The data are recordings of naturally occurring interactions on a helpline. The corpus consists of 396 recorded calls to the Victim Support helpline collected in 2015-2016. Calls range in length from 15 seconds to 20 minutes, although over half of the total sample are less than two minutes long.

\section{Ethics}

The Contact Service routinely record calls for training purposes. A pre-recorded message informs callers they can request recording be halted at any time. The organisation amended this message and their online privacy statement to state that recordings could also be used for research. Contact service workers provided written consent to have their calls included in the research sample and could remove recordings they did not wish to have included in the sample.

Sound files have been edited to anonymise identifying information such as names, addresses, or contact details. Pseudonyms are used in the transcripts below.

\section{Analytic procedure}

In this discursive psychology study of identity and help, I used the microanalytic method of conversation analysis to examine how requests for help were rendered intelligible and accountable through participants' orientations to identity.

Recorded calls were listened to repeatedly and catalogued according to details such as call length, outcome (e.g. call transfer) and incident type (e.g. burglary). Recordings have been progressively transcribed following lines of analytic enquiry. Transcription follows conversation analytic conventions developed by Jefferson (2004) and Hepburn (2004) which captures features of interaction including the length of silences, the speed, volume, and intonation of utterances, and when more than one person is speaking at once.

To examine the relationship between identity and help-seeking, I formed a collection of 104 cases where callers presented their reason for calling. I limited cases to those where callers were seeking help for themselves, with 'seeking help' conceptualised in the broadest terms. Rather than operating with a pre-determined definition of what help is, I undertook to document how participants understood the action of help. My analytic focus was how helpseeking was rendered intelligible. Using the next-turn-proof procedure (Sacks et al., 1974), I examined how callers designed help-seeking turns and how call-takers responded to them.

Following Schegloff (1997), I did not presume when or how identity would matter for helpseeking but documented how participants' orientations to identity were procedurally 
consequential for the trajectory of the call. Only in rare cases did participants use explicit category terms. When these occurred, I used membership categorisation analysis (Sacks, 1967, 1972a, 1972b) to examine the link between categories, activities, rights, and responsibilities. I combined these observations with attention to where categories occurred in the sequential unfolding of the interaction and how participants oriented to their relevance for the ongoing activity of seeking help (see Stokoe, 2012). When explicit identities were not referenced, I drew upon Stevanovic and Peräkylä's (2014) framework to examine how helpseeking was rendered intelligible through participants' orientations to identity. I analysed how participants' turns encoded epistemic, deontic, or affective stances that displayed their understanding of their identities and social relationships with their recipient.

\section{Analysis}

I analyse how categorical relationships and terrains of knowledge, power, and emotion are resources for participants to intelligibly build and accountably interpret actions as helpseeking on the victim support helpline. I first examine how callers' epistemic and deontic rights as clients of the service rendered certain requests intelligible and accountable. Next, I show how affective stance could establish callers' identities as victims seeking emotional support. Finally, I demonstrate how the link between identity and help was negotiated when callers sought help while distancing themselves from a victim identity.

\section{Seeking help as clients}

In Extract 1, the caller's help-seeking request displays an epistemic and deontic stance towards the kind of help available and how it can be asked for. I analyse how this request makes identities relevant for both caller (CL) and call-taker (CT). The call opens with the standard institutional greeting, including the Māori greeting "kia ora" (line 1).

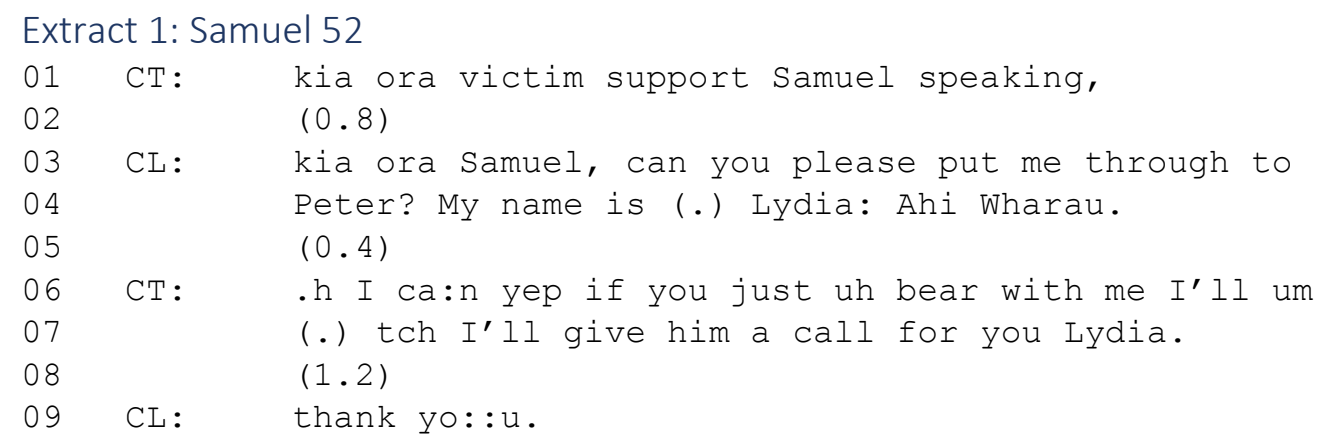

The way the caller asks for help displays her understanding of who she is to her recipient and who he is to her (Stevanovic \& Peräkylä, 2014). Although the call-taker identified as a member of the institutional category "victim support" (line 1), the caller displays an understanding that the help available during the call is not support. Instead, her request to be "put...through" (line 3) displays her understanding of the 'switchboard' function of the Contact Service (cf. Psathas, 1999) and her recipient's role in transferring calls.

The design of the caller's request displays an epistemic stance of knowledge about the kind of help available and how the service operates. This epistemic stance invokes the caller's identity as a client of the service with rights to knowledge in this domain (see Heritage, 2012). She refers to the person she wishes to speak to by first name, while identifying herself with first and surname (line 4). First name references are a way to display someone known in 
common between speaker and recipient, while full names do not convey the same expectation of recognition (Schegloff, 1996). The caller thus displays that Peter is someone she knows and expects the call-taker to know, while she does not expect him to recognise her by her first name alone. A primary role of the victim helpline is to connect clients to support workers, and here the first name reference is inferentially available as the caller's support worker. The caller's reference to herself and others thus displays her understanding of her recipient's domain of knowledge, invoking his identity as a contact service worker.

The participants' identities as client and contact service worker are also made visible through their orientations to their respective deontic rights. The caller displays a deontic stance that she is entitled to help with the modal verb "can" (line 3 ) in an interrogative question (Curl \& Drew, 2008). The design of her requests suggests transfer lies in her recipient's deontic domain, but that she has the rights to determine what help she needs and how to ask for it. By moving to grant the request (lines 6-7), Samuel confirms transferring calls is an action he can carry out and which the caller is entitled to seek.

In Extract 1, the caller's first turn conveys an epistemic and deontic stance that constitutes her identity as a client and renders intelligible her request to be transferred to her support worker. In Extract 2, the caller's identity as a client is likewise constituted through epistemic and deontic stance. However, the participants have different understandings of the relationship between identity and help. They resolve this misunderstanding with explicit reference to the caller's identity as a victim.

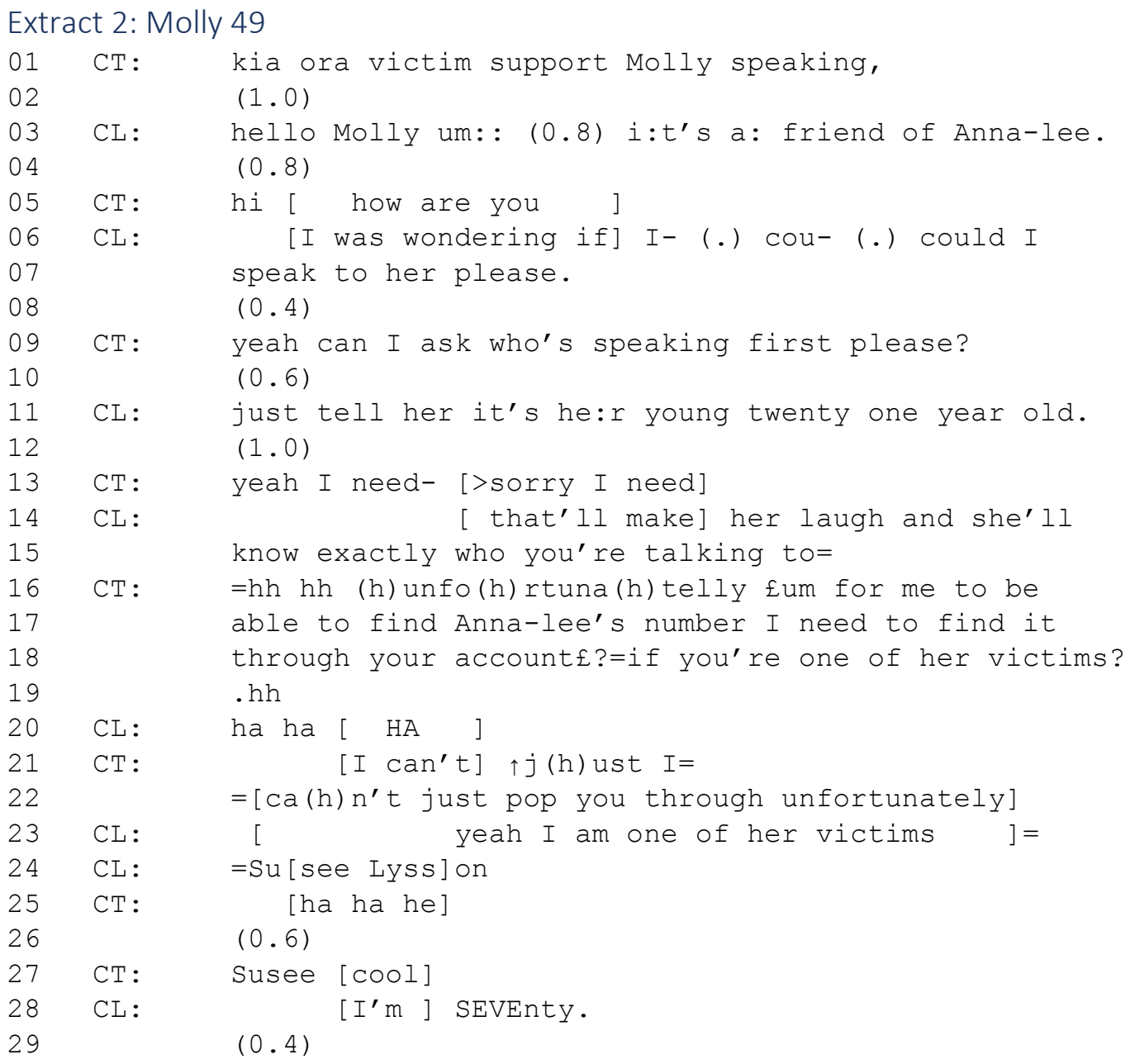




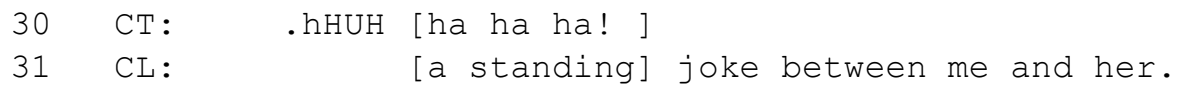

Much like Extract 1, the caller's request to be transferred displays a deontic stance towards her rights to determine how help should be provided. However, she identifies herself quite differently. After greeting the call-taker, the sound-stretched "um::" and nearly a second of silence display a trouble in speaking which she resolves by categorising herself as "a: friend of Anna-lee." (line 3). Rather than giving her name, the caller identifies in a way that displays her relationship with the person she is calling to speak to. Although the caller configures this relationship as a friendship, participants' mutual orientation to the institutional context of the call means the caller's identity is inferentially available as a client of the service.

However, the call-taker treats the caller's identification as incompatible with the institutional framework. Her request (line 9) is understood differently by the participants. The caller understands the turn as granting her request and asking how to introduce her once the call is transferred. The call-taker, however, understands the turn as an insertion sequence, which must be dealt with before she can respond to the caller's request (see Schegloff, 2007b). In response to the call-taker's identification request, the caller uses an alternative recognitional reference (Stivers, 2007), "he:r young twenty one year old" (line 11) which she claims will make Anna-lee "laugh" (line 14) and be sufficient for her to "know exactly" who she is (line $15)$.

Although the call-taker concedes the alternative recognitional may very well be sufficient for Anna-lee's recognition (and laughter at line 16 displays affiliation with the caller's affective stance), she displays that this form of identification is insufficient for present purposes. She describes the practical process of carrying out a transfer (accessing the support worker's details through the caller's casefile) and orients to her own and the caller's identity. By describing constraints on her institutional role, the call-taker orients to her identity as a contact service worker, whose ability to carry out the request rests on the caller's compliance with institutional procedures (i.e. identifying in an institutionally recognised way). This description makes explicit the link between the provision of help and the caller's identity. The call-taker claims her ability to grant the request is conditional on the caller's identity as "one of her victims" (line 18). Thus here, a breakdown in intersubjectivity regarding how the caller made her request is resolved by the call-taker attributing the caller as a member of the category victim.

Extracts 1 and 2 demonstrate that requesting transfer can display both epistemic and deontic stances towards the available help and how it can be accessed. These requests are accountable and intelligible through the social relations between callers as clients and call-takers as contact service workers. However, a client identity in this context is predicated upon victimhood, an inference which can be made explicit when joint understanding breaks down.

\section{Seeking help as victims}

Callers seeking help in the absence of an established relationship with the organisation build their requests for help differently. Although self-categorisations are rare in the dataset, one recurrent place where they occurred was in initial help-seeking requests such as Extract 3 below. 


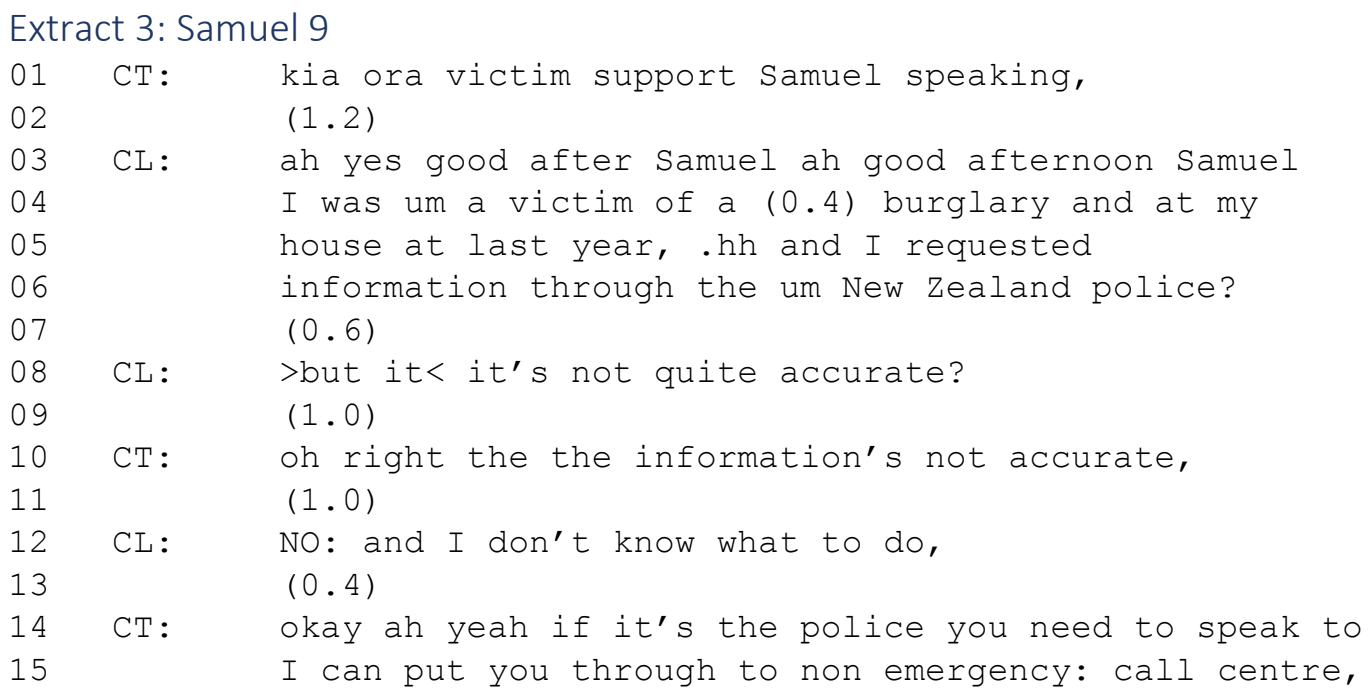

By categorising herself as "a victim of a (0.4) burglary" (line 4) the caller makes explicit the link between identity and action. The caller displays an understanding that her action of seeking help is accountable as an entitlement of her category membership. The caller's social identity relative to the problem provides for her entitlement to seek help (M. Whalen \& Zimmerman, 1990). Claiming category membership can make relevant blame-allocation techniques like accusations and complaints (Watson, 1978). By categorising herself as a victim, the caller treats receiving inaccurate information from police as blame-worthy, presenting this as the complainable situation for which she has now turned to Victim Support for help.

The caller builds her request across multiple turns of talk. She first establishes her entitlement as a victim (to receive help both from police and from Victim Support) and then presents her problem: receiving inaccurate information about the burglary. She finishes with "I don't know what to do," (line 12) a sequence closing device that marks the conclusion of her troubles telling and indicates a response from the call-taker is now relevant (Emmison \& Danby, 2007). Seeking help in this way displays the caller's relative unknowing epistemic stance about the nature of the help available. By directing her request to help to her recipient, the caller attributes to him the ability to know and provide help. The caller thus invokes the caller taker's identity an institutional representative of a service designed to support victims.

However, the call taker's response displays a deontic stance that locates responsibility for the problem with police. Offering to transfer the call (lines 14-15) reconfigures the relations between parties from advice-seeker/advice-provider to one where he can offer certain forms of help (i.e. transfer) but not others (Hepburn et al., 2018; Jefferson \& Lee, 1992).

In Extract 4 below, the caller does not name the category victim but provides a narrative that makes this membership category inferentially available. Narrative descriptions are formats that allow callers to manage issues of motive and knowledge in emergency calls and helplines (Potter \& Hepburn, 2003; Zimmerman, 1992). In this case, both caller and call-taker link the caller's experience with her identity as a victim and her need for support. 
Extract 4: Tom 1

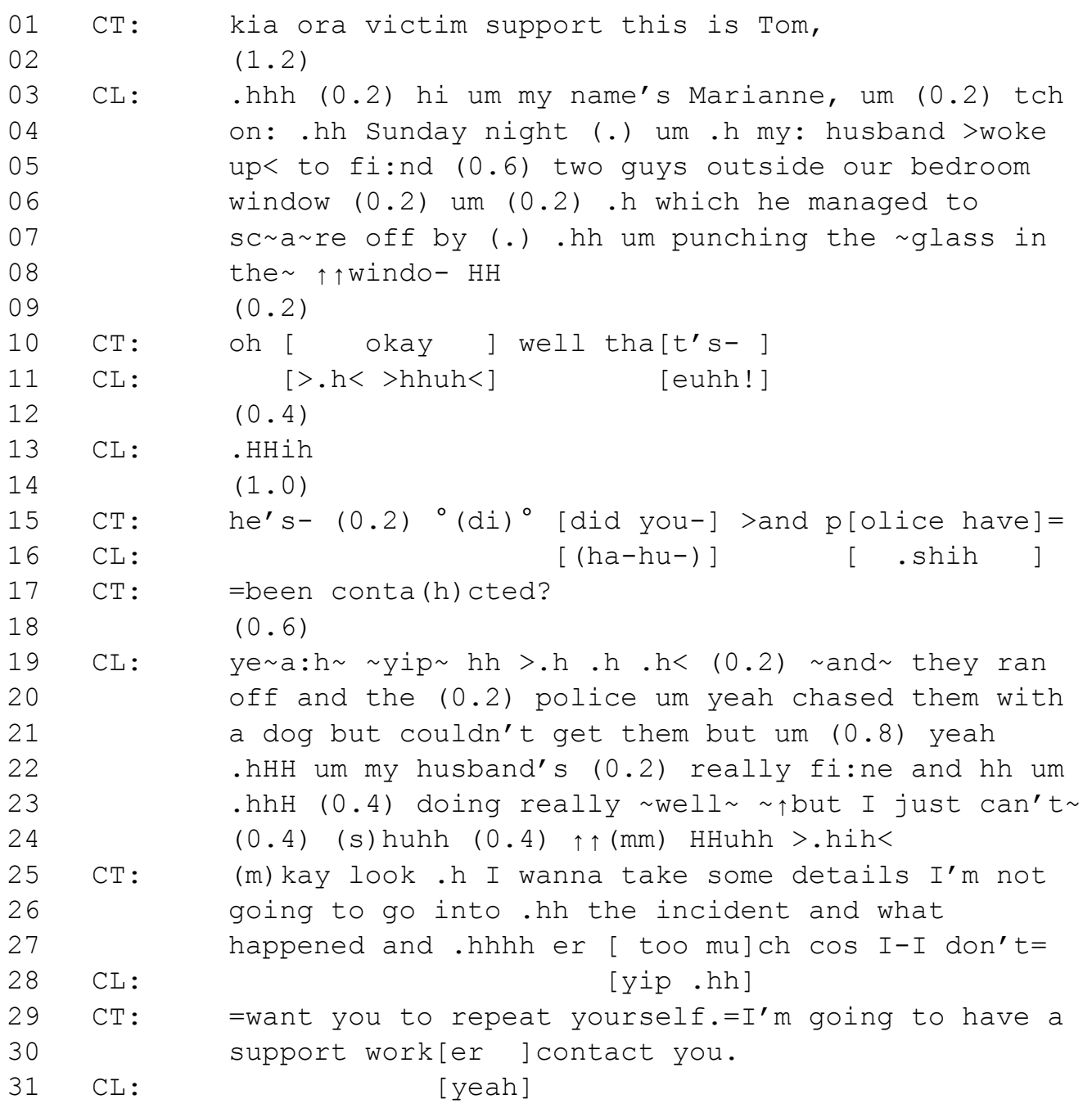

The caller's a narrative description displays (without saying so directly) that she is seeking emotional support as a victim. She begins her story by recounting recent events that took place "on: .hh Sunday night" (line 4). This call takes place at night two days later. Thus, the caller's story is a description of recent events, which are demonstrably still impacting her. She describes a trespassing event (lines 4-8) and demonstrates the traumatic nature of this experience when crying overwhelms her ability to speak (line 8). This 'flooding out' of emotion (Goffman, 1961) displays her social position relative to the events describes - as a victim affected by her experience. In a context where emotional support is a relevant form of help, this affective stance is a key resource for building and interpreting the request for help (see Stevanovic \& Peräkylä, 2014). The caller displays her understanding of the help available by explicitly formulating her husband's and her own emotional states. Although he is "doing really $\sim$ well " (line 23), she both claims (" ^but I just can’t $\sim$ " line 23) and demonstrates (with a second flooding out at line 24) her inability to cope. The caller's affective stance thus claims the rights to own and display emotions regarding the events, which positions her as a traumatised victim entitled to receive emotional support from the service.

Although the call-taker treats the caller as a legitimate victim entitled to receive help from the service, he orients to his deontic rights to determine how help will be provided and in doing so, 
makes relevant his identity as a contact service worker. By directing her story to the call-taker, the caller displayed an expectation he possessed the knowledge and competencies to meet her needs (Psathas, 1999). It is not unreasonable to assume that someone who identifies as a member of Victim Support (line 1) can provide support to victims. Yet rather than providing support, the call-taker uses "look" (line 25) to indicate his next action is not directly fitted to the caller's prior turn (see Sidnell, 2007). The call-taker orients to potential misalignment between participants by naming the category "a support worker" (line 30) and characterising his actions as details-gathering. The activity of providing emotional support is bound to the category support workers, while contact service workers like himself only have the categorybound rights and competencies to allocate support workers. In this offer of help, the call-taker formulates the Contact Service as a conduit to help, clarifying that help in the here-and-now takes the form of arranging support rather than providing it directly (cf. Watson, 1986).

As Extract 4 demonstrates, an affective stance can make recognisable an identity (as a victim) and an action (seeking help). However, as Extract 5 below demonstrates, the link between identity and help is a negotiated accomplishment.

\section{Extract 5: Sharika 2}

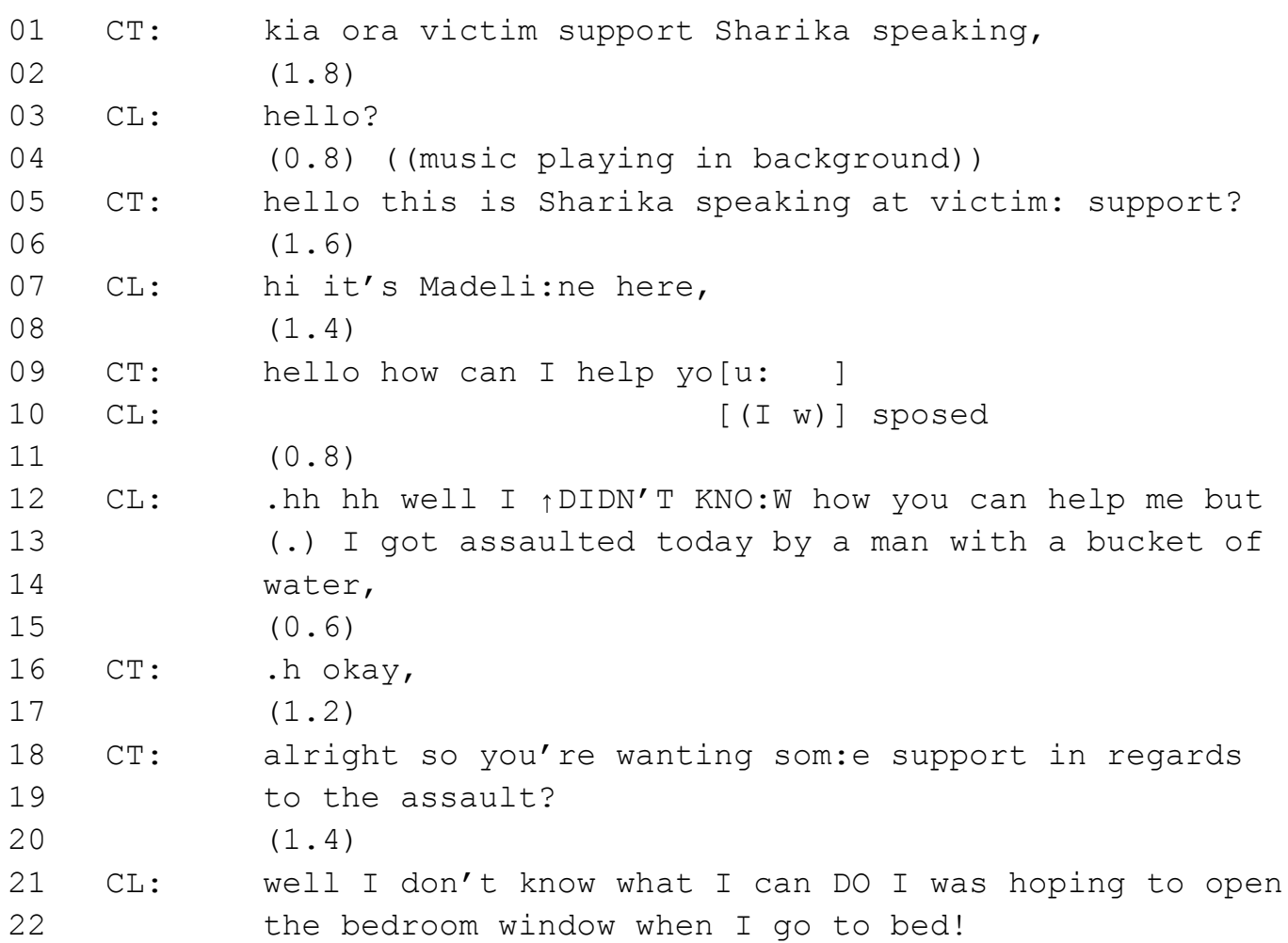

The routine call opening (line 1) and the modified repeat (line 5) identify the call-taker as a representative of Victim Support. When the call-taker pursues a reason for the call by asking "how can I help you:" (line 9), she displays the presumption that the caller is seeking help and implies a request is a relevant way to ask for it. The call-taker's action invokes her identity as a help-provider and projects the caller's identity as a help-seeker.

Yet the caller challenges the presumption that calling the helpline is linked to her identity as a help-seeker. Rather than producing a type-fitted response (Schegloff, 2007) to the call-taker's question (such as a request for service), she displays an epistemic stance that disavows 
knowledge about what help she needs. She claims the reason she is calling is because she "got assaulted today" (line 13). This description makes her categorical identity as a victim inferentially available. Yet by disavowing knowledge of how the call-taker (or organisation) can help her, the caller inverts the relationship between victims and help seen in Extract 4 . Although the caller invokes an identity as a victim, her lack of knowledge about the service constrains her ability to request specific help.

Nevertheless, the call-taker treats the caller's description as a request for help. Her request for confirmation displays her understanding that the caller is "wanting som:e support in regards to the assault" (line 18-19). Using the definite article "the", the call-taker transforms the caller's description into categorisation (Stokoe, 2009), treating assault as a relevant institutional problem. Someone with a relevant institutional problem for victim support is, by definition, a victim. The declarative format "you're wanting som:e support" (line 18) displays the calltaker's understanding that this was the action of the caller's turn, which she is now merely confirming, rather than proposing for the first time. The caller rejects this understanding, claiming the epistemic rights to formulate her reason for calling. She treats her problem (opening the window) as not straightforwardly associated with support. Presenting mundane needs is one way helpline callers can claim identities as ordinary people rather than clients in need of help (te Molder, 2005). The caller's response challenges the call-taker's displayed understanding that she (and the organisation she represents) can help the caller. Although both participants orient to the caller as a victim entitled to help, they negotiate just what form this help should take.

The inferential framework of the victim support helpline means that simply by calling and describing a relevant experience, callers can be understood to be seeking support (cf. Zimmerman, 1992). However, not all callers know what the service offers or how it operates. The link between a victim identity and a request for help is thus a joint accomplishment. The final section examines this accomplishment by demonstrating how callers navigate helpseeking when their relationship to victimhood is less straightforward. The cases provide further evidence that participants orient to the relationship between identity and help when building and interpreting requests on the helpline.

\section{Seeking help while negotiating victimhood}

Requests for certain forms of help invoke different relationships to victimhood. In Extract 6 below, the caller designs her request to challenge the inference that someone seeking help from Victim Support is necessarily a victim.

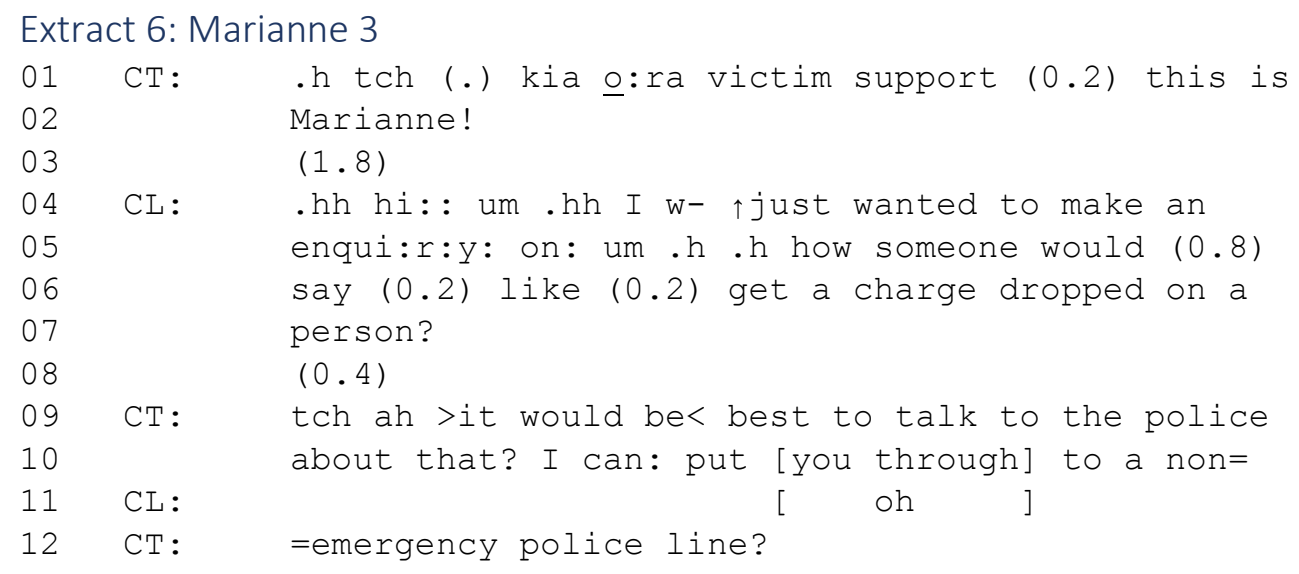


The caller displays an understanding that, by virtue of calling the victim helpline, she may be understood as a victim. Her use of reference forms manages the inferences that can be drawn about her from her request for help. The non-recognitional reference "someone" (line 5) is regularly used when speakers presume their recipients do not know (or need to know) the person referred to (Schegloff, 1996). By deviating from the unmarked reference "I" (line 3), the caller displays that she is not necessarily seeking help for herself, pushing back on the inference that seeking help from Victim Support makes her a victim. Likewise, using the indefinite article to refer both to "a charge" and "a person" (line 6) neutralises inferences about the relationship between the people involved. (Contrast this with a description like $m y$ ex-partner is in prison which makes inferentially available relational and victim-perpetrator categories; citation blinded for review).

Even though the caller distances herself from a victim identity, she displays an expectation that the call-taker - and the institution she represents - can provide the help she is seeking. However, the call-taker displays a different understanding of how the caller can be helped. Rather than answering the caller's enquiry, she provides advice. The design of the advice, " $>$ it would be $<$ best to talk to the police" (line 8), matches the caller's design of her request, presenting the advice as general course of action rather than something the caller specifically should do (see Emmison \& Firth, 2012; Vayreda \& Antaki, 2009).

The call-taker's offer uses the modal verb "can" (line 10) to present the proposed course of action as something she is able and willing to do. Proposal offers in this format index a low deontic stance that allow recipients to assess the offered course of action (Hofstetter \& Stokoe, 2015). Thus, the call-taker orients to her identity as a service-provider who can offer forms of help (e.g. transferring calls) which callers can choose to accept. By offering to transfer the call, the call-taker also indicates that access to such information is not associated with her categorical role as a contact service worker, but instead lies in the domain of police call-takers. Thus, while denying the organisation's ability to help the caller, the call-taker highlights her individual ability to help the caller by transferring her.

In the final extract, the caller orients to the accountability associated with seeking help in the absence of a legitimate victim identity.

\section{Extract 7: Jenny 2}

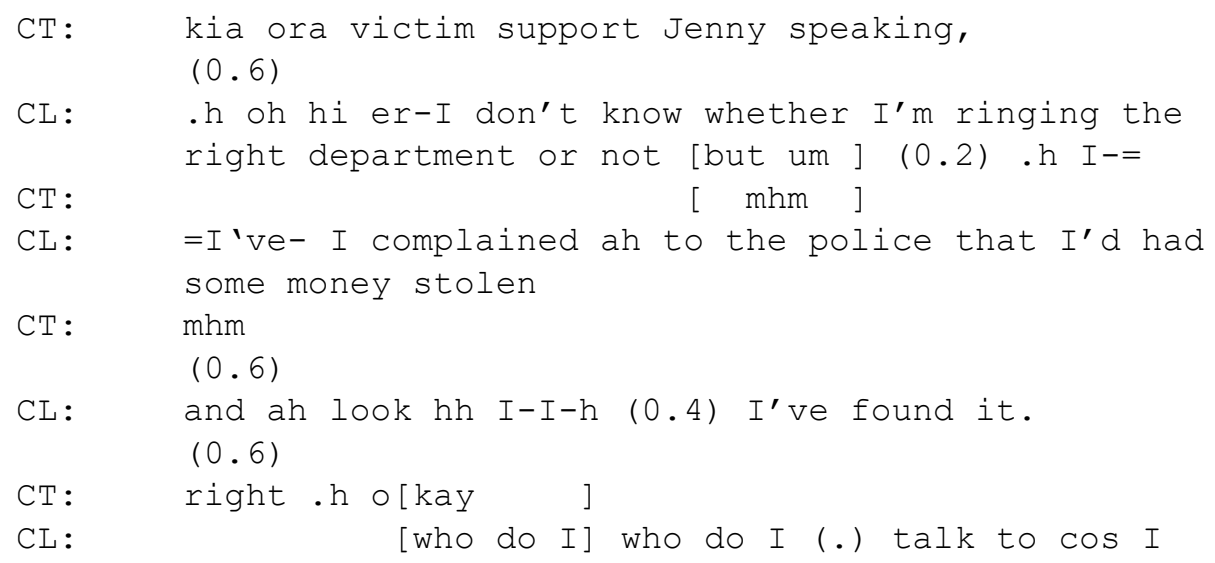




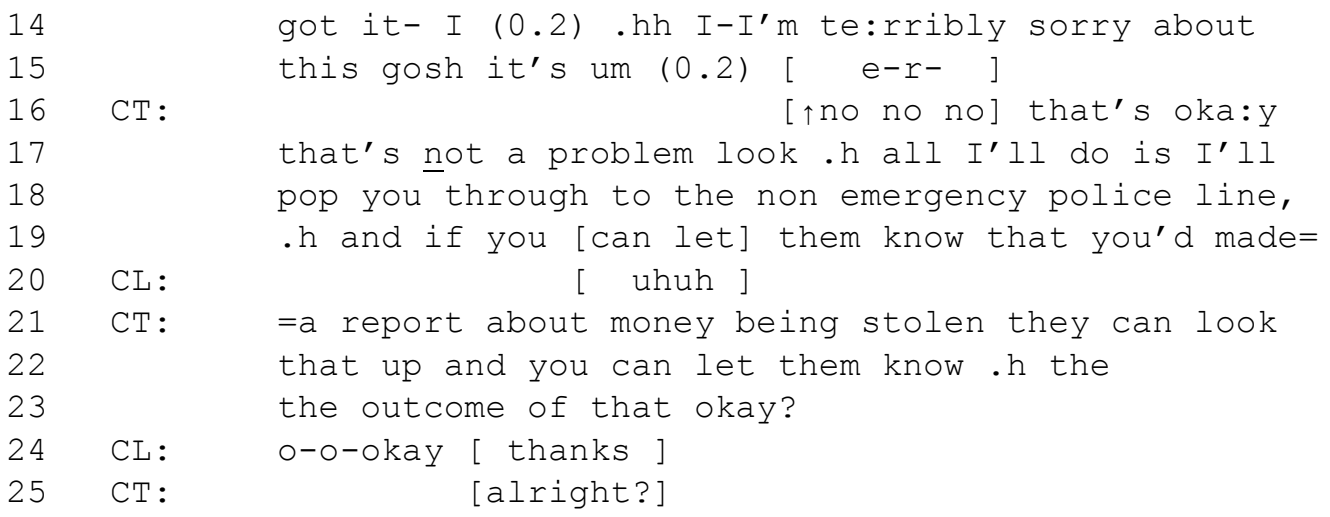

The caller's description of different versions her problem (lines 4-10) demonstrates the consequential ways identity and action can be linked (see Cuff, 1993). She first describes complaining about stolen money (lines 6-7), an activity which makes her identity as a victim relevant. This identity is associated with entitlement to seek help from police. However, the caller's second description, of having "found" the money (line 10) re-categorises both herself and her problem. If the money was not stolen, but lost, her problem is not a crime. And if the caller has not experienced a crime, she is not a victim. Furthermore, if she is not a victim, she is not entitled to police help. Complaining to police about stolen money is a victim's right. Complaining to police about lost money makes different inferences available about her identity and motives (see Jayyusi, 1984). Thus, different versions of reality make different inferences available regarding the caller's identity and her rights to help.

Caller and call-taker display different stances on the accountability of the caller's action. The caller treats her actions as morally accountable through an incomplete account (line 13), explicit apology (line 14), stance marker "gosh", and perturbations in talk (line 15), which display her affective stance of upset. The call-taker, however, uses the multiple saying "no no no" (line 17) to cut short the progression of the caller's apologies (Stivers, 2004) and explicitly claims "that's not a problem" (line 18). The call-taker displays an understanding that the institution does not merely provide help to victims but can provide help with issues associated with victimhood. The call-taker treats the caller as entitled to ask for help and offers to transfer the call (lines 17-23). The design of the call-taker's request displays a deontic stance that transfer is a form of help the caller is entitled to. She minimises the costs of her action with the preface "all I'll do" and the description "pop you through" (line 18) to display that granting the caller's request is no imposition, but a form of help she can readily provide (Clayman \& Heritage, 2014). In this way, she invokes her identity as a service provider, and establishes the caller's reciprocal deontic entitlement to request and receive services from the organisation although ultimately the resolution of her problem lies with police.

\section{Discussion}

In calls to the victim helpline, participants jointly accomplished the link between identity and help. Requests for help invariably invoked identities for both callers and call-takers by configuring epistemic, deontic, and affective relations between participants. When callers requested to be transferred to support workers, they displayed an epistemic stance of knowing about the workings of the organisation and a deontic stance of being entitled to request services. The design of such requests constituted their identities as clients and their recipients' identities as contact service workers. When callers described experiences, their affective stances 
constituted their identities as victims and their recipients' identities as support providers. However, call-takers' responses to such descriptions oriented to callers' lack of knowledge about the service by specifying call-takers' identities as contact service workers rather than support workers.

Simply turning to Victim Support was enough for callers to be understood as victims seeking help. However, the connection between actions and identities posed challenges for certain forms of help-seeking. Callers seeking advice about dropping charges or a mistaken police report oriented to the way their previous actions (i.e. pressing charges; reporting a crime) would have been sufficient for others to ascribe their identities as victims. Although seeking help for problems related to victimhood, these callers designed their requests to undercut the assumption they were seeking help as victims. Thus, the link between a victim identity and a request for help is a joint accomplishment negotiated between participants.

Help-seeking was rendered accountable through participants' shared sense of who they were to each other. Identity and social relations were resources for participants to build and interpret actions as requests for help. Callers' identities as clients or victims rendered their help-seeking accountable. In the absence of linguistically designed requests, descriptions of experience or presentation of problems were understood as help-seeking through the epistemic, deontic, and affective relationships between participants. Callers' identities also rendered their help-seeking morally accountable. Participants oriented to category-bound rights associated with being a victim or a client of the service.

Identity and help are mutually constitutive. Asking for help constituted callers' identities as victims; and callers' identities as victims constituted their requests for help. Participants oriented to this mutually constitutive link, displaying an understanding that seeking help implicates claims to identity. These orientations were particularly explicit in cases where callers sought help that called their victimhood into question. Callers negotiated how they should be understood relative to the help they were seeking. Although not everyone seeking help from Victim Support necessarily claims victimhood, participants oriented to the way that help-seeking in this context invariably invokes identity. Interactional research has shown that the nature of help sought is consequential for how requests are built and interpreted (Drew \& Couper-Kuhlen, 2014), while my analyses show that the nature of the help sought is also consequential for how identities are constituted and used.

The mutually constitutive relationship between identity and help is particularly salient in the context of a victim support service. Determining who victims are and how they should be helped is a contentious moral and political enterprise (Simmonds, 2009). Although the organisation views the helpline as a conduit to service, call-takers are engaged in consequential decisions about callers' victimhood and whether they can be helped. Victim Support bears similarities to helplines like Kids Help Line and MensLine that specify a category of person as help-seeker. Despite the common-sense use of these category terms, determining callers' relevant identities and what constitutes help is a joint accomplishment (see Butler et al., 2010; Danby et al., 2005; Feo \& LeCouteur, 2013, 2017). When callers lack knowledge about the service, participants may be misaligned regarding who-they-are-toeach-other and the kind of help available (cf. Stokoe, 2013).

One problem that regularly occurs on the Victim Support helpline is that callers ask for kinds of help which cannot be given. The misalignment between the help callers seek and what 
institutional representatives can provide has been documented in a range of other settings including counselling helplines (Butler et al., 2010), dispute resolution services (Weatherall, 2015), and medical information lines (Butler et al., 2009). In some cases, the name of the service can exacerbate such misalignment. For example, callers to the Child Health Line regularly seek medical advice which nurse call-takers cannot provide. Butler and colleagues (2009) noted that callers' requests displayed an expectation nurses have professional authority and expertise to give advice when in fact nurses are trained only to provide information and support. On the Victim Support helpline, callers display similar expectations of receiving support from call-takers directly, while call-takers are not trained to provide this form of help. In some cases, call-takers corrected callers' displayed misunderstanding by identifying themselves as contact service workers and specifying the role of support workers. Callers' expectations of receiving help in the here and now of the call seem exacerbated by the advertisement of 0800 Victim as a helpline and the way that call-takers answer the phone by identifying as "victim support". One solution would be to change the routine opening, such as by identifying as the Victim Support Contact Service, or for call-takers to explain their role to callers when offering referral. This could be accompanied by clearer advertising about the role of the helpline.

Although the mutually constitutive relationship between identity and help is particularly salient in institutional contexts like helplines, I argue that identity and action are always inexorably linked. Any request for help necessarily implicates identities for speaker and recipients. Even in mundane interaction, different methods of recruiting help configure self-other relations in terms of obligation or opportunity to help (Kendrick \& Drew, 2016). Likewise, identity is a resource that participants use to make sense of help-seeking as social action (see Horne \& Wiggins, 2009). Identity is not fixed, but constituted in different ways at different moments of interaction (Benwell \& Stokoe, 2006).

In interaction, identity is inseparable from self-other relations. People identify differently depending on who they understand their recipient to be and what they are doing at any given moment. Participants use their moment-by-moment understanding of who they are to each other as a resource for building recognisable actions (Stevanovic \& Peräkylä, 2014). By integrating Sacks' $(1967,1972 a, 1972 b)$ insights with recent developments in the interactional organisation of social relations (Stevanovic \& Peräkylä, 2014), this paper demonstrates how rights, entitlements, and obligations to help are constituted and understood through participants' sense of who they are to each other. Different predicates like rights, obligations, and knowledge can be bound to different category membership (Psathas, 1999; Stokoe, 2009). My analyses show that participants orient to different category-bound rights to know about themselves and others, determine how help will be given, and express or respond to emotion.

Although Stevanovic and Peräkylä's (2014) theoretical framework was developed to explain how actions are built and interpreted in interaction, this grounded approach to identity and action has broader relevance for psychology. The ways people use and orient to knowledge, power, and emotion are fundamental psychological concerns. The connections between knowledge and social relations are intrinsic to social psychology (see Raymond \& Heritage, 2006), while analysing deontics can provide an interactional demonstration of psychological concepts like authority and coercion (see Clift, 2016). Discursive psychology has examined how emotions are described or formulated (Edwards, 1999), and how emotions are displayed and responded to in interaction (Hepburn \& Potter, 2007, 2017). Yet the way affect is 
associated with different identity categories, and how affect and help are interrelated deserves further investigation. On the Victim Support helpline, affect has common-sense associations with both a victim identity and the kind of help available. Affective stances can accomplish a request for help and constitute a caller's identity as a victim. There are thus productive possibilities for analysing the relationships between affect, identity, and help.

\section{Concluding comments}

The relationship between identity and action is a fundamental question for social psychology. With a focus on the action of help-seeking, this paper has documented how participants orient to identity and help as mutually constitutive in calls to a victim helpline. Help-seeking was rendered both intelligible and accountable through participants' orientation to their identities and social relations. Identity and action are intertwined phenomenon that can be examined through participants' moment-by-moment attention to the epistemic, deontic, and affective aspects of who they are to each other. 


\section{References}

Benwell, B., \& Stokoe, E. (2006). Discourse and Identity. Edinburgh University Press.

Butler, C., Danby, S., Emmison, M., \& Thorpe, K. (2009). Managing medical advice seeking in calls to Child Health Line. Sociology of Health \& Illness, 31(6), 817-834. https://doi.org/10.1111/j.1467-9566.2009.01179.x

Butler, C., Potter, J., Danby, S., Emmison, M., \& Hepburn, A. (2010). Advice-implicative Interrogatives: Building “Client-centered” Support in a Children’s Helpline. Social Psychology Quarterly, 73(3), 265-287. https://doi.org/10.1177/0190272510379838

Clayman, S. E., \& Heritage, J. (2014). Benefactors and beneficiaries: Benefactive status and stance in the management of offers and requests. In P. Drew \& E. Couper-Kuhlen (Eds.), Studies in Language and Social Interaction (Vol. 26, pp. 55-86). John Benjamins Publishing Company. https://doi.org/10.1075/slsi.26.03cla

Clift, R. (2016). The structure of sequences II: knowledge and authority in the construction of identity. In Conversation Analysis (pp. 185-231). Cambridge University Press.

Cuff, E. C. (1993). Problems of Versions in Everyday Situations. International Institute for Ethnomethodology and Conversation Analysis \& University Press of America.

Curl, T. S., \& Drew, P. (2008). Contingency and Action: A Comparison of Two Forms of Requesting. Research on Language \& Social Interaction, 41(2), 129-153. https://doi.org/10.1080/08351810802028613

Danby, S., Baker, C., \& Emmison, M. (2005). Four observations on openings in calls to Kids Help Line. In C. Baker, M. Emmison, \& A. Firth (Eds.), Calling for help: Language and social interaction in telephone helplines (pp. 133-151). John Benjamins.

Drew, P., \& Couper-Kuhlen, E. (2014). Requesting - from speech act to recruitment. In P. Drew \& E. Couper-Kuhlen (Eds.), Studies in Language and Social Interaction (Vol. 26, pp. 1-34). John Benjamins Publishing Company. https://doi.org/10.1075/slsi.26.01dre 
Edwards, D. (1998). The Relevant Thing about Her: Social Identity Categories in Use. In C. Antaki \& S. Widdicombe (Eds.), Identities in Talk (pp. 15-33). SAGE Publications.

Edwards, Derek. (1999). Emotion Discourse. Culture \& Psychology, 5(3), 271-291. https://doi.org/10.1177/1354067X9953001

Edwards, Derek, \& Stokoe, E. (2007). Self-Help in Calls for Help With Problem Neighbours. Research on Language \& Social Interaction, 40(1), 9-32. https://doi.org/10.1080/08351810701331208

Emmison, M., \& Danby, S. (2007). Troubles Announcements and Reasons for Calling: Initial Actions in Opening Sequences in Calls to a National Children's Helpline. Research on Language \& Social Interaction, 40(1), 63-87. https://doi.org/10.1080/08351810701331273

Emmison, M., \& Firth, A. (2012). Requesting and receiving advice on the telephone: An analysis of telephone helplines in Australia. In H. Limberg \& M. A. Locher (Eds.), Pragmatics \& Beyond New Series (Vol. 221, pp. 213-232). John Benjamins Publishing Company. https://doi.org/10.1075/pbns.221.13emm

Farmer, C., Farrand, P., \& O’Mahen, H. (2012). 'I am not a depressed person': How identity conflict affects help-seeking rates for major depressive disorder. BMC Psychiatry, 12(1). https://doi.org/10.1186/1471-244X-12-164

Feo, R., \& LeCouteur, A. (2013). 'I just want to talk': Establishing Reason for Call on a Men's Counselling Helpline. Australian Feminist Studies, 28(75), 65-80. https://doi.org/10.1080/08164649.2012.759310

Feo, R., \& LeCouteur, A. (2017). Dealing with third-party complaints on a men's relationship-counselling helpline. Discourse Studies, 19(2), 131-147. https://doi.org/10.1177/1461445617691701

Garfinkel, H. (1967). Studies in ethnomethodology. Prentice-Hal. 
Garfinkel, H. (2002). Ethnomethodology's program: working out Durkeim's aphorism. Rowman \& Littlefield Publishers.

Giles, D. (2006). Constructing identities in cyberspace: The case of eating disorders. British Journal of Social Psychology, 45(3), 463-477. https://doi.org/10.1348/014466605X53596

Goffman, E. (1961). Encounters. Two studies in the sociology of emotion. Bobbs-Merrill Company, Inc.

Hepburn, A. (2004). Crying: Notes on Description, Transcription, and Interaction. Research on Language and Social Interaction, 37(3), 251-290. https://doi.org/10.1207/s15327973rlsi3703_1

Hepburn, A., \& Potter, J. (2007). Crying Receipts: Time, Empathy, and Institutional Practice. Research on Language and Social Interaction, 40(1), 89-116. https://doi.org/10.1080/08351810701331299

Hepburn, A., \& Potter, J. (2017). Crying and Crying Responses. In A. Peräkylä \& M.-L. Sorjonen (Eds.), Emotion in Interaction. Oxford University Press.

Hepburn, A., Shaw, C., \& Potter, J. (2018). Advice Giving and Advice Resistance on Telephone Helplines. In E. MacGeorge \& L. Van Swol (Eds.), The Oxford Handbook of Advice (pp. 153-174). Oxford University Press.

Heritage, J. (1990). International Accountability: a Conversation Analytic Perspective. Réseaux, 8(1), 23-49. https://doi.org/10.3406/reso.1990.3529

Heritage, J. (2012). The Epistemic Engine: Sequence Organization and Territories of Knowledge. Research on Language \& Social Interaction, 45(1), 30-52. https://doi.org/10.1080/08351813.2012.646685 
Heritage, J., \& Clayman, S. (2010). Gatekeeping and Entitlement to Emergency Service. In Talk in Action: Interactions, Identities, and Institutions (pp. 69-86). John Wiley \& Sons, Incorporated.

Hofstetter, E., \& Stokoe, E. (2015). Offers of assistance in politician-constituent interaction. Discourse Studies, 17(6), 724-751. https://doi.org/10.1177/1461445615602376

Hogg, M. A., Terry, D. J., \& White, K. M. (1995). A tale of two theories: A critical comparison of identity theory with social identity theory. Social Psychology Quarterly, 58(4), 255-269. https://doi.org/10.2307/2787127

Horne, J., \& Wiggins, S. (2009). Doing being 'on the edge': managing the dilemma of being authentically suicidal in an online forum. Sociology of Health \& Illness, 31(2), 170184. https://doi.org/10.1111/j.1467-9566.2008.01130.x

Jaspal, R., Carriere, K. R., \& Moghaddam, F. M. (2016). Bridging Micro, Meso, and Macro Processes in Social Psychology. In J. Valsiner, G. Marsico, N. Chaudhary, T. Sato, \& V. Dazzani (Eds.), Psychology as the Science of Human Being (pp. 265-276). Springer International Publishing. https://doi.org/10.1007/978-3-319-21094-0_15

Jayyusi, L. (1984). Categorization and the Moral Order. Routledge \& Kegan Paul. Jefferson, G. (2004). Glossary of transcript symbols with an introduction. In G. Lerner H. (Ed.), Conversation Analysis. Studies from the first generation (pp. 13-31). John Benjamins Publishing Company.

Jefferson, G., \& Lee, J. (1992). The rejection of advice: managing the problematic convergence of a "troubles-telling" and a "service encounter." In P. Drew \& J. Heritage (Eds.), Talk at work: Interaction in institutional settings (pp. 521-548). Cambridge University Press. 
Kendrick, K. H., \& Drew, P. (2016). Recruitment: Offers, Requests, and the Organization of Assistance in Interaction. Research on Language and Social Interaction, 49(1), 1-19. https://doi.org/10.1080/08351813.2016.1126436

Lamerichs, J., \& te Molder, H. F. M. (2003). Computer-Mediated Communication: From a Cognitive to a Discursive Model. New Media \& Society, 5(4), 451-473. https://doi.org/10.1177/146144480354001

Levinson, S. C. (2013). Action Formation and Ascription. In T. Stivers \& J. Sidnell (Eds.), The Handbook of Conversation Analysis (pp. 103-130). Wiley.

Löfstrand, C. H. (2009). Understanding Victim Support as Crime Prevention Work: The Construction of Young Victims and Villains in the Dominant Crime Victim Discourse in Sweden. Journal of Scandinavian Studies in Criminology \& Crime Prevention, 10(2), 120. https://doi.org/10.1080/14043850903316220

Miller, P. A., Sinding, C., Griffith, L. E., Shannon, H. S., \& Raina, P. (2016). Seniors' narratives of asking (and not asking) for help after a fall: implications for identity. Ageing and Society, 36(02), 240-258. https://doi.org/10.1017/S0144686X14001123

Mondada, L. (2013). Displaying, contesting and negotiating epistemic authority in social interaction: descriptions and questions in guided visits. Discourse Studies, 15(5), 597626. https://doi.org/10.1177/1461445613501577

O’Doherty, L. J., Taft, A., McNair, R., \& Hegarty, K. (2016). Fractured Identity in the Context of Intimate Partner Violence: Barriers to and Opportunities for Seeking Help in Health Settings. Violence Against Women, 22(2), 225-248. https://doi.org/10.1177/1077801215601248

Potter, J., \& Hepburn, A. (2003). “I'm a Bit Concerned”--Early Actions and Psychological Constructions in a Child Protection Helpline. Research on Language and Social Interaction, 36(3), 197-240. https://doi.org/10.1207/S15327973RLSI3603_01 
Psathas, G. (1999). Studying the organization in action: Membership categorization and interaction analysis. Human Studies, 22(2-4), 139-162. https://doi.org/10.1023/A:1005422932589

Raymond, G., \& Heritage, J. (2006). The Epistemics of Social Relations: Owning Grandchildren. Language in Society, 35(5), 677-705. https://doi.org/10.1017/S0047404506060325

Read, S. A., Morton, T. A., \& Ryan, M. K. (2015). Negotiating identity: a qualitative analysis of stigma and support seeking for individuals with cerebral palsy. Disability and Rehabilitation, 37(13), 1162-1169. https://doi.org/10.3109/09638288.2014.956814

Sacks, H. (1967). The search for help: no one to turn to. In E. S. Shneidman (Ed.), Essays in self destruction (pp. 203-223). Science House.

Sacks, H. (1972a). An initial investigation of the usability of conversational data for doing Sociology. In D. N. Sudnow (Ed.), Studies in Social Interaction (pp. 31-74). Free Press.

Sacks, H. (1972b). On the Analyzability of Stories by Children. In J. J. Gumperz \& D. Hymes (Eds.), Directions in Sociolinguistics: The Ethnography of Communication (pp. 325-345). Holt, Rinehart and Winston, Inc.

Sacks, H., Schegloff, E. A., \& Jefferson, G. (1974). A simplest systematics for the organization of turn-taking for conversation. Language, 50(4), 696-735. http://dx.doi.org/10.17323/1728-192X-2015-1-142-202

Schegloff, E. A. (1996). Some Practices for Referring to Persons in Talk-in-Interaction: A Partial Sketch of a Systematics. In B. A. Fox (Ed.), Studies in Anaphora (pp. 437486). John Benjamins.

Schegloff, E. A. (1997). Whose Text? Whose Context? Discourse \& Society, 8(2), 165-187. https://doi.org/10.1177/0957926597008002002 
Schegloff, E. A. (2007). Sequence Organisation in Interaction. Cambridge University Press.

Sidnell, J. (2007). 'Look'-prefaced turns in first and second position: launching, interceding and redirecting action. Discourse Studies, 9(3), 387-408. https://doi.org/10.1177/1461445607076204

Simmonds, L. (2009). What victims want! Victim Support, and objective or relative approach to victims' needs. Social \& Public Policy Review, 3(2), 11-29.

Smithson, J., Sharkey, S., Hewis, E., Jones, R. B., Emmens, T., Ford, T., \& Owens, C. (2011). Membership and Boundary Maintenance on an Online Self-Harm Forum. Qualitative Health Research, 21(11), 1567-1575. https://doi.org/10.1177/1049732311413784

Stevanovic, M., \& Peräkylä, A. (2014). Three orders in the organization of human action: On the interface between knowledge, power, and emotion in interaction and social relations. Language in Society, 43(02), 185-207. https://doi.org/10.1017/S0047404514000037

Stivers, T. (2004). "No no no" and Other Types of Multiple Sayings in Social Interaction. Human Communication Research, 30(2), 260-293. https://doi.org/10.1111/j.14682958.2004.tb00733.x

Stivers, T. (2007). Alternative recognitionals in person reference. In N. J. Enfield \& T. Stivers (Eds.), Person Reference in Interaction (pp. 73-96). Cambridge University Press. https://doi.org/10.1017/CBO9780511486746.005

Stokoe, E. (2009). Doing actions with identity categories: complaints and denials in neighbor disputes. Text \& Talk - An Interdisciplinary Journal of Language, Discourse Communication Studies, 29(1), 75. https://doi.org/10.1515/TEXT.2009.004 
Stokoe, E. (2012). Moving forward with membership categorization analysis: Methods for systematic analysis. Discourse Studies, 14(3), 277-303.

https://doi.org/10.1177/1461445612441534

Stokoe, E. (2013). Overcoming Barriers to Mediation in Intake Calls to Services: ResearchBased Strategies for Mediators. Negotiation Journal, 29(3), 289-314. https://doi.org/10.1111/nejo.12026

Stokoe, E., \& Edwards, D. (2009). Accomplishing Social Action with Identity Categories: Mediating and Policing Neighbour Disputes. In M. Wetherell (Ed.), Theorizing Identities and Social Action (pp. 95-115). Palgrave Macmillan UK. https://doi.org/10.1057/9780230246942_6

Tajfel, H., \& Turner, J. (1986). The social identity theory of intergroup behavior. In S. Worchel \& W. Austin (Eds.), Psychology of Intergroup Relations (pp. 7-24). Nelson Hall.

te Molder, H. (2005). "I just want to hear somebody right now”. Managing identities on a telephone helpline. In C. Baker, M. Emmison, \& A. Firth (Eds.), Calling for help: Language and social interaction in telephone helpliens (pp. 153-172). John Benjamins.

Vayreda, A., \& Antaki, C. (2009). Social Support and Unsolicited Advice in a Bipolar Disorder Online Forum. Qualitative Health Research, 19(7), 931-942. https://doi.org/10.1177/1049732309338952

Watson, D. R. (1978). Categorization, Authorization, and Blame-Negotiation in Conversation. Sociology, 12(1), 105-113. https://doi.org/10.1177/003803857801200106

Watson, D. R. (1986). Doing the Organization's Work: An Examination of Aspects of the Operation of a Crisis Intervention Center. In S. Fisher \& A. D. Todd (Eds.), Discourse 
and Institutional Authority: Medicine, Education, and Law (pp. 91-120). Ablex Publishing Company.

Weatherall, A. (2015). “But whose side are you on?” Doing being independent in telephonemediated dispute resolution. In F. H. G. Chevalier \& J. Moore (Eds.), Producing and Managing Restricted Activities: Avoidance and withholding in institutional interaction (Vol. 255, pp. 151-179). John Benjamins Publishing Company.

Whalen, M. R., \& Zimmerman, D. (1990). Describing Trouble: Practical Epistemology in Citizen Calls to the Police. Language in Society, 19(4), 465-492. https://doi.org/10.1017/s0047404500014779

Wiggins, S., McQuade, R., \& Rasmussen, S. (2016). Stepping Back From Crisis Points: The Provision and Acknowledgment of Support in an Online Suicide Discussion Forum. Qualitative Health Research, 26(9), 1240-1251. https://doi.org/10.1177/1049732316633130

Zimmerman, D. (1992). The interactional organization of calls for emergency assistance. In P. Drew \& J. Heritage (Eds.), Talk at Work (pp. 418-469). Cambridge University Press. 